\title{
LINGKUNGAN DAN PERANNYA SEBAGAI SUMBER PEMBELAJARAN IPS
}

\author{
Rahmaniah \\ Email: 2010128320006@mhs.ulm.ac.id \\ Program Studi Pendidikan IPS Fakultas Keguruan dan Ilmu Pendidikan \\ Universitas Lambung Mangkurat \\ Banjarmasin
}

\begin{abstract}
Abstrak
IPS merupakan suatu program pendidikan yang membahas tentang interaksi atau hubungan antar sesama makhluk hidup (individu dengan individu atau kelompok dengan individu atau sebaliknya). Lingkungan sekitar sebagai sumber belajar dan pembelajaran sangat menguntungkan bagi proses pembelajaran IPS, hal ini disebabkan karena sumber belajar dekat dengan siswa, sehingga siswa lebih mudah dalam proses memahami sumber belajar. Lingkungan mampu memberikan sebuah gambaran yang sifatnya holistik dan autentik (dapat dipercaya), kondisinya sangat beragam, sehingga menunjukkan suatu sumber pembelajaran yang memerlukan keterpaduan antar materi pembelajaran. Potensi lingkungan ini bisa berupa lingkungan sosial, ekonomi, budaya dan geografi. Mengkaitkan kelas dengan lingkungan masyarakat memberikan banyak kesempatan kepada siswa untuk mempelajari kemampuan dasar untuk melakukan tindakan (action) di masyarakat dalam bentuk partisipasi.
\end{abstract}

\section{PENDAHULUAN}

IPS yang juga dikenal dengan nama Social Studies memiliki pengertian yaitu suatu kajian mengenai manusia dengan segala aspeknya dalam system kehidupan bermasyarakat. IPS mengkaji bagaimana manusia berinteraksi dengan sesamanya baik di lingkungan sendiri, dengan tetangga yang dekat sampai jauh, ataupun di lingkungan sekitar. IPS juga mengkaji bagaimana manusia bergerak dan bagaimana manusia dapat memenuhi kebutuhan hidupnya. Dengan demikian IPS mengkaji tentang keseluruhan kegiatan yang dilakukan oleh manusia. Kehidupan yang bersifat kompleksitas yang akan dihadapi siswa nantinya tentu bukan hanya akibat dari tuntutan perkembangan 
ilmu dan teknologi saja, melainkan juga kompleksitas kemajemukan masyarakat Indonesia. Oleh karena itu, IPS berupaya mengembangkan pengetahuan dan keterampilan yang berhubungan dengan manusia dan juga tindakan-tindakan empatik yang melahirkan pengetahuan tersebut.

Perkembangan IPS sebagai mata pelajaran di sekolah memiliki cakupan materi yang semakin meluas. Mengingat semakin kompleks dan rumitnya permasalahan sosial maka diperlukan kajian secara terintegrasi dari berbagai disiplin ilmu sosial, ilmu pengetahuan alam, teknologi, humaniora, lingkungan, bahkan sistem kepercayaan. Dengan cara tersebut maka diharapkan pula pendidikan IPS ini terhindar dari sifat ketinggalan zaman dan keberadaannya juga diharapkan tetap koheren dengan perkembangan sosial yang terjadi.

Peran lingkungan sekitar sebagai sumber belajar sangat menguntungkan bagi proses pembelajaran, hal yang demikian disebabkan karena sumber belajar dekat dengan siswa, sehingga siswa lebih mudah dalam proses memahami sumber belajar tersebut. Lingkungan mampu memberikan sebuah gambaran yang sifatnya holistik dan autentik (dapat dipercaya), kondisinya sangat beragam, sehingga menunjukkan suatu sumber pembelajaran yang memerlukan keterpaduan antar materi pembelajaran. Oleh karena itu memberikan suatu tantangan bagi pendidik untuk dapat pula mengembangkan metode pembelajaran yang variatif, dengan memanfaatkan lingkungan sebagai sumber belajar, terlebih sebagai sumber pembelajaran IPS.

\section{IPS SEBAGAI TRANSFORMASI SOSIAL}

Transformasi sosial mempunyai arti perubahan-perubahan yang terjadi di masyarakat baik dalam bentuk sifat, watak, dan struktur. Dalam melakukan hubungan timbal bail sebagai individu dengan individu ataupun kelompok dengan kelompok. Adapun pengertian transformasi social menurut beberapa ahli yaitu sebagai berikut:

a. William F.ogburn: perubahan sosial adalah perubahan yang mencakup unsur-unsur kebudayaan baik material maupun inmaterial.

b. Kingsley Davis: perubahan sosial merupakan perubahan-perubahan yang terjadi dalam struktur dan fungsi masyarakat. 
c. Mac Iver: perubahan sosial merupakan perubahan-perubahan kebudayaan yang terjadi dalam hubungan sosial atau perubahan terhadap keseimbangan hubungan sosial.

d. Gillin dan Gillin: perubahan sosial adalah perubahan yang terjadi sebagai suatu variasi dari cara hidup yang telah diterima karena adanya perubahan kondisi geografi, kebudayaan material, komposisi penduduk, ideology, maupun adanya difusi atau penemuan-penemuan baru dalam masyarakat.

Hakikat IPS sebagai transformasi sosial sebuah tradisi di masyarakat IPS yang mendorong siswa untuk membawa perubahan sosial di masyarakat.

Tujuan dari IPS sebagai transformasi sosial di masyarakat yaitu:

1. Siswa mampu menyesuaikan diri dengan perubahan-perubahan sosial yang terjadi di masyarakat.

2. Mampu memberikan solusi kepada masyarakat tentang masalah-masalah sosial.

3. Siswa dapat menciptakan perubahan yang lebih baik di masyarakat.

4. Siswa harus mampu mempertahankan kebudayaan dan nila-nilai yang baik dari bangsanya.

Metode pembelajaran IPS sebagai tranformasi sosial untuk membimbing siswa dalam menyelesaikan masalah didalam masyarakat antara lain sebagai berikut:

1. Problem solving, yaitu pemecahan masalah yang ada di masyarakat yang kemudian dibawa guru kedalam kelas untuk didiskusikan.

2. Discovery learning, yaitu menentukan solusi atau konsep dari suatu permasalahan untuk diberikan kepada masyarakat guna menyelesaikan masalah yang ada.

3. Pembelajaran proyek, yaitu siswa diajak langsung untuk ikut serta dalam proyek pembangunan sosial.

\section{PENGARUH LINGKUNGAN TERHADAP KESEJAHTERAAN MANUSIA DAN MAKHLUK HIDUP}

Lingkungan sangat berpengaruh bagi kelangsungan hidup dan kesejahteraan manusia serta makhluk hidup, manusia akan selalu berinteraksi dengan segala unsur yang ada dalam lingkungan, dan hubungannya bersifat saling mempengaruhi. Dari berbagai unsur atau komponen alam, manusia merupakan komponen yang paling dominan apabila dibandingkan dengan makhluk hidup lainnya. Karena manusia 
dikaruniai akal dan pikiran yang dapat berkembang dan dapat dikembangkan. Pengaruh manusia terhadap lingkungan alam sangat dipengaruhi oleh IPTEK yang dikuasai oleh manusia itu sendiri.

Pengaruh manusia terhadap lingkungan tidak merata karena dipengaruhi oleh bagaimana manusia mampu mengembangkan budaya dalam menguasai IPTEK (Nursid Sumaatmaja, 1998). Kemampuan memanfaatkan potensi lingkungan oleh manusia tergantung pada kemampuan kebudayaan kelompok manusia itu dalam merealisasikan potensi sumber daya lingkungan yang ada menjadi kekayaan yang menjamin kesejahteraannya. Masyarakat yang sudah mampu mengembangkan budayanya dan mampu menguasai IPTEK, mereka tidak hanya mampu dalam memanfaatkan sumber daya lingkungannya sendiri, tetapi mereka juga mampu dalam menguasai sumber daya lingkungan negeri lain. Sebaliknya, bagi masyarakat yang belum mampu mengembangkan budaya IPTEK secara memadai, maka potensi sumber daya alam lingkungannya tidak dapat dimanfaatkan untuk kesejahteraannya.

\section{PERANAN LINGKUNGAN SEBAGAI SUMBER BELAJAR IPS}

Sumber belajar yang digunakan dalam proses pembelajaran IPS akan lebih mudah dipahami oleh peserta didik apabila guru dapat memanfaatkan lingkungan disekitar. Potensi lingkungan sangat beragam, sehingga merupakan sumber belajar yang potensial dan mudah ditemui serta dipahami oleh peserta didik. Potensi lingkungan ini bisa berupa lingkungan sosial, budaya, ekonomi, dan geografi. Lingkunga sosial dapat berupa polapola interaksi yang dilakkan oleh masyarakat, kesadaran akan manfaat pendidikan, mobilitas social, kesehatan dan hidup bersih. Lingkungan ekonomi berupa mata pencharian masyarakat setempat, potensi wisata, kegiatan ekonomi masyarakat sekitar, bentuk-bentuk usaha masyarakat. Lingkungan budaya dapat berupa adat istiadat masyarakat, gya hidup masyarakat dan keberagaman agama atau kepercayaan. Lingkungan geografi misalnya berupa relief bumi, cuaca, letak geografis dll.

Di era globalisasi yang ditandai dengan perubahan IPTEK yang begitu cepat, maka diperlukan dimensi-dimensi untuk menghadapi kehidupan secara efektif dalam kondisi sumber daya alam yang semakin menipis dan ditandai dengan keragaman etnis, pluralisme budaya dan semakin saling ketegantungan. Untuk menyiapkan siswa agar dapat menghadapi berbagai tantangan dalam kehidupan, maka dalam pembelajaran 
bidang studi IPS perlu dikembangkan kepekaan sosial dan partisipasi sosial. Kepekaan sosial (social sensitivity) diperlukan agar siswa mudah bereaksi tehadap masalahmasalah sosial dan masyarakat. Alam kehidupan masyarakat terdapat banyak masalah dan akan menjadi bagian perhatian dari siswa, sehingga perlu dikembangkan sejak awal. Pengembangan strategi pembelajaran yang dilakukan guru bidang studi IPS hendaknya dapat mendorong siswa untuk peka terhadap masalah-masalah yang ada di lingkungan sekitarnya. Kepekaan sosial dapat dikembangkan melalui proses pembelajaran dan pelatihan, sehingga siswa mempunyai pengalaman individual pada masa lampau.

Dengan belajar IPS hendaknya dapat memberdayakan siswa, sehingga segala potensi dan kemampuanya baik pengetahuan, sikap, maupun ketrampilan dapat berkembang. Menurut Jaromelik dan Parker dalam Sapriya (2011) mengemukakan bahwa ujian yang sesungguhnya dalam belajar IPS terjadi ketika siswa berada di luar sekolah. Berdasarkan pendapat tersebut guru bidang studi IPS dalam pembelajarannya hendaknya mempunyai tujuan menyiapkan siswa untuk mampu menemukan, memahami dan dapat menghadapi berbagai permasalahan yang ada di lingkungannya. Agar siswa dapat memahami lingkungannya dengan baik, maka guru bidang studi IPS sudah selayaknya menggunakan potensi yang ada di sekitarnya baik potensi geografi, sosial, ekonomi dan budaya sebagai sumber belajar maupun media belajar. Mediamedia sekitar sebetulnya mempunyai potesial untuk membantu siswa dalam melaksanakan pendekatan inkuiri dan melatih keterampilan siswa untuk berpikir secara kritis.

Keterkaitan kelas dengan lingkungan masyarakat memberikan banyak kesempatan kepada siswa untuk mempelajari kemampuan dasar untuk melakukan tindakan (action) di masyarakat dalam bentuk partisipasi. Di dalam masyarakat terdapat sejumlah kegiatan yang memungkinkan siswa dapat melakukan tindakannya antara lain: kegiatan sosial politik, proyek kemasyarakatan, proyek sosial (sukarelawan), studi kemasyarakatan, permagangan dan program model. Untuk dapat memberikan berbagai ketrampilan yang dibutuhkan siswa, sebaiknya guru bidang studi IPS betul-betul memanfaatkan potensi lingkungannya sebagai sumber belajar dan media belajar. Oleh karena itu dapat dikatakan bahwa guru bidang studi IPS masih banyak yang tidak memanfaatkan potensi sekitarnya dalam pembelajaran, sehingga sumber belajar yang berdasarkan potensi sekitar belum dikembangkan secara maksimal. 


\section{SIMPULAN}

Peran lingkungan sekitar sebagai sumber belajar sangat menguntungkan bagi proses pembelajaran, hal yang demikian disebabkan karena sumber belajar dekat dengan siswa, sehingga siswa lebih mudah dalam proses memahami sumber belajar tersebut. Lingkungan mampu memberikan sebuah gambaran yang sifatnya holistik dan autentik (dapat dipercaya), kondisinya sangat beragam, sehingga menunjukkan suatu sumber pembelajaran yang memerlukan keterpaduan antar materi pembelajaran. Oleh karena itu memberikan suatu tantangan bagi pendidik untuk dapat pula mengembangkan metode pembelajaran yang variatif, dengan memanfaatkan lingkungan sebagai sumber belajar, terlebih sebagai sumber pembelajaran IPS.

Mengkaitkan kelas dengan lingkungan masyarakat memberikan banyak kesempatan kepada siswa untuk mempelajari kemampuan dasar untuk melakukan tindakan (action) di masyarakat dalam bentuk partisipasi.Sesuai dengan tujuan pembelajaran IPS yang bertujuan mendorong siswa berpikir kritis, sehingga bidang studi IPS bukanlah bidang studi yang mudah dalam penyampainya, namun sebagian orang beranggapan bahwa IPS cukup disampaikan dengan cara menghafal atau mengingat saja.

\section{REFERENSI}

Abbas, E. W. (2015). Pendidikan IPS Berbasis Kearifan Lokal. WAHANA Jaya Abadi. Abbas, E. W., Permatasari, M. A., Mutiani, M., Saidinor, S., Budianto, A., \& Hasanaini, H. (2019). IMPLEMENTASI MODEL KOOPERATIF DALAM PEMBELAJARAN IPS UNTUK MENINGKATKAN PENGETAHUAN KESADARAN LINGKUNGAN PESERTA DIDIK (Studi Pada SMP Negeri 6 Banjarmasin).

Arwinda, A. (2019). Paradigma Pembelajaran.

Ischak, dkk, Pendidikan IPS di SD, (Jakarta: Universitas Terbuka, 2005)

Jumriani, J., \& Anwar, A. (2019). PENGARUH LINGKUNGAN PENGENDALIAN TERHADAP FRAUD PADA LAPORAN KEUANGAN PEMERINTAH 
DAERAH KOTA PAREPARE. Economos: Jurnal Ekonomi dan Bisnis, 2(2), 7986.

Mariati, M., Abbas, E. W., \& Mutiani, M. (2021). The Social Science Contribution Through Social Studies Learning. The Innovation of Social Studies Journal, 2(2), 110-120.

Mutiani, M., Sapriya, S., Handy, M. R. N., Abbas, E. W., \& Jumriani, J. (2021). Pembinaan Etika Peserta Didik Melalui Pembelajaran Tematik-Integratif Di Sekolah Dasar. Edukatif: Jurnal Ilmu Pendidikan, 3(3), 704-709.

Nasution, Toni dan Lubis Maulana Arafat Konsep Dasar Ilmu Pengetahuan Sosial, Yogyakarta: Samudra Biru, 2018.

Putro, H. P. N., \& Jumriani, J. (2020). KEHIDUPAN SOSIAL DAN EKONOMI MASYARAKAT BANTARAN SUNGAI A SEBAGAI SUMBER BELAJAR IPS.

Syaharuddin, S., Handy, M. R. N., Jumriani, J., Faisal, M., \& Maulana, I. (2020). The Values of Gotong Royong on BPK (Fire Brigade) Social Activities in Banjarmasin. The Kalimantan Social Studies Journal, 2(1), 62-68.

Syaharuddin, S., Samihati, M., \& Jumriani, J. (2020). AKTUALISASI SIKAP PEDULI LINGKUNGAN MELALUI AKTIVITAS PENGELOLAAN SAMPAH. Jurnal Socius, 9(2), 193-203.

Widiastuti, E. H. (2017). Pemanfaatan Lingkungan Sebagai Sumber Pembelajaran Mata Pelajaran IPS. Satya Widya, 33(1), 29-36. 